The Colombian Political Agendas Project: analysing presidential attention during the administrations of Uribe and Santos (2002-2018)

\author{
Juan Guillermo Vieira Silva ${ }^{1}$ \\ Jeraldine Alicia del Cid Castro ${ }^{2}$ \\ 1 Universidad Autónoma de Manizales / Departamento de Ciencias Políticas y Jurídicas, Manizales - Colombia \\ 2 Facultad Latinoamérica de Ciencias Sociales, FLACSO México, Ciudad de México - México
}

\begin{abstract}
This article has two interrelated objectives: to introduce the Colombian Political Agendas Project (COL-PAP) and offer an exploratory example of the applications of its databases. As a prelude, we describe some characteristics of the Colombian political system and the presidents analyzed. The study presents the objectives of COL-PAP, the creation of the codebook and the databases built so far, with special attention to the databases gathering bills and CONPES documents. The example discussed explores the dynamics of presidential attention in the period 2002-2018, especially the attention distributed among public policy issues over time, and its allocation among instruments. The study shows that attention varies among issues, but also that it is assigned differently between instruments, according to the opportunity structure they offer. Inspired in the discussion and findings related to the databases built so far for COL-PAP, the study suggests future lines of research for Colombia, Latin America, and the CAP in general.
\end{abstract}

Keywords: presidential attention; comparative agendas project; Colombian political agendas project; Colombian politics; public policy.

\title{
0 Projeto de Agendas Políticas da Colômbia: análise da atenção presidencial durante as administrações de Uribe e Santos (2002-2018)
}

Este artigo tem dois objetivos inter-relacionados: apresentar o Projeto Agendas Políticas Colombianas (COL-PAP) e apresentar um exemplo exploratório das aplicações que podem ser feitas com suas bases de dados. Como um prelúdio, descrevemos algumas características do sistema político colombiano e dos presidentes analisados. Com relação ao COL-PAP relatamos seus objetivos, a construção do livro de códigos e as bases de dados construídas até o momento, com especial atenção aos de Projetos de Lei e CONPES. Em relação ao exemplo, estamos interessados em explorar a dinâmica da atenção presidencial no período 2002-2018, em particular sua distribuição entre questões de políticas públicas ao longo do tempo, e sua alocação entre instrumentos. Sustentamos que a atenção varia entre as questões, mas também que ela é alocada de forma diferente entre os instrumentos, de acordo com a estrutura de oportunidades que eles oferecem. Apresentamos os resultados com respeito a estes aspectos e terminamos deixando algumas linhas futuras de pesquisa para a Colômbia, América Latina e a PAC em geral, tanto da exploração apresentada como das bases de dados construídas até o momento para o COL-PAP.

Palavras-chave: atenção presidencial; projeto de agendas comparativas; projeto de agendas políticas da Colômbia; política colombiana; políticas públicas. 


\section{El Proyecto de Agendas Políticas de Colombia: análisis de la atención presidencial durante las administraciones de Uribe y Santos (2002-2018)}

Este artículo tiene dos objetivos interrelacionados: introducir el Proyecto de Agendas Políticas Colombianas (COL-PAP) y presentar un ejemplo exploratorio de las aplicaciones que se pueden hacer con sus bases de datos. Como preludio, describimos algunas características del sistema político colombiano y de los presidentes analizados. Respecto al COL-PAP damos cuenta de sus objetivos, la construcción del libro de códigos y las bases de datos construidas hasta ahora, con especial atención a las de Proyectos de Ley y CONPES. En relación con el ejemplo, nos interesa explorar la dinámica de atención presidencial en el periodo 2002-2018, en particular su distribución entre asuntos de políticas públicas en el tiempo, y su asignación entre instrumentos. Sostenemos que la atención varía entre asuntos, pero también que se asigna de forma diferenciada entre los instrumentos, de acuerdo con la estructura de oportunidad que ofrecen. Presentamos los hallazgos respecto a estos aspectos, y terminamos planteando algunas líneas futuras de investigación para Colombia, Latinoamérica y el CAP (Comparative Agendas Project) en general, tanto a partir de la exploración presentada como desde las bases de datos construidas hasta ahora para el COL-PAP.

Palabras clave: atención presidencial; proyecto de agendas comparadas; proyecto de agendas políticas de Colombia; política colombiana; políticas públicas.

\section{ACKNOWLEDGMENTS}

The authors thank Juan Carlos Vinasco Ossa and Rafael Ricardo Tostes, who work for the translation center of the Universidad Autónoma de Manizales, for translating and proofreading this article into Portuguese.

\section{INTRODUCTION}

This article introduces the Colombian Political Agendas Project (COL-PAP) and shows an exploratory example of the applications that can be done with their databases. The COL-PAP aims to be part of the Comparative Agendas Project (CAP) ${ }^{1}$, which is an international comparative project dedicated to the analysis of political attention, built on the use of a shared coding system. Its data infrastructure allows to reconstruct the political agendas of each country by collecting information on various indicators of public action, such as laws, bills, media, hearings, decrees, among others.

The COL-PAP was originated as part of a doctoral thesis on the dynamics of Colombia's presidential legislative agenda, inspired by the broader interest of studying the role of the president in the policy process. This concern remains and is located on the structuring axis of the COL-PAP proposal, which basically has two objectives: 1) to collect and codify the political agendas of various institutions, especially in the executive, legislative and judicial branches, as well as the media and public opinion, in order to analyze their interactions and dynamics over time, 2) to introduce the study approaches of the political agendas associated with the CAP to analyze the Colombian political dynamics, while broadening the comparison horizon within the CAP community to developing countries.

In addition to introducing the COL-PAP we make a first approach to the dynamics of presidential attention in Colombia through the bills of presidential origin, and the CONPES ${ }^{2}$. The first are legislative

\footnotetext{
${ }^{1}$ Retrieved from https://www.comparativeagendas.net/

${ }^{2}$ Documents issued by the National Economic and Social Policy Council.
} 
proposals addressed to Congress and the latter are decisions made by the executive. The analysis focuses on the governments of former Presidents Alvaro Uribe (2002-2010) and Juan Manuel Santos (2010-2018), whom we characterize along with some aspects of Colombia's political system post-1991 constitution.

The study on the dynamics of presidential attention from the perspective of the CAP is practically non-existent in Latin America, with the exception of the doctoral thesis of Aranda-Jan (2018) which analyses presidential speeches in Mexico to account for the dynamics of presidential prioritization, and the nascent Brazilian project within the CAP which is mainly focused in executive attention (Brasil, Capella, \& Fagan, 2020). Furthermore, the comparative politics literature on Latin America recognizes that the presidents of the region have an enormous capacity to set agendas but their analyses focus on the ability to define the agenda of Congress (Cheibub-Figueiredo, Pérez-Liñán, \& Martins-Vieira, 2009; Santos, Pérez-Liñán, \& García Montero, 2014).

Attention to issues is the essence of CAP (Walgrave \& Boydstun, 2019, p. 36), but, in part because of the scarcity of presidentialisms ${ }^{3}$ within its 22 member countries, presidential attention studies are limited to the United States. However, there is a relevant group of analyses that address political attention in several parliamentary systems executives (Baumgartner, Brouard, \& Grossman, 2009; Borghetto, Visconti, \& Michieli, 2017; Breeman et al., 2009; Dowding, Hindmoor, Iles, \& John, 2010; Jennings, Bevan, \& John, 2011; Mortensen et al., 2011). In particular, they discuss the role of coalitions in agenda-setting dynamics, as well as the hypothesis that partisan preferences affect the attention level to certain public affairs (Baumgartner et al., 2009; Borghetto et al., 2017), which in our opinion are not relevant features for the analysis in Colombia.

Our proposal is close to most of the above-mentioned body of work, which examine how attention has shifted to different issues over time (Breeman et al., 2009) or account for which issues have gone up or down in importance within the executive agendas (Dowding et al., 2010). In our case, we explored the distribution of presidential attention between public policy issues over time, and their allocation between instruments (Bills and CONPES). In this aspect, we distance ourselves from the referred work to get closer to another emerging line within the CAP that combines the prioritization of policy issues and instruments to analyze presidential attention in the United States (Eissler, 2016, 2018; Larsen-Price, 2012). They basically argue that each instrument involves a particular structure of opportunity that affects the allocation of attention to policy issues (Larsen-Price, 2012, p. 154), which implies for the presidents an effort to process information on the political and policy contexts, on their situation in them and on the possibilities that each instrument offers for their public policy objectives.

While this article has mainly descriptive and exploratory purposes, we assume the above statement as a general working hypothesis to analyze the interaction between presidential attention to both policy issues and instruments. We argue that the character of the instruments does affects the prioritization of issues, and that the presidential decision process to combine issues and instruments is also influenced by other contextual and institutional factors such as the character of the presidency and the political time. That is the reason we chose bills and CONPES. The former are mediated by Congress and the latter are unilateral, which allows us to explore whether there is a differentiated use of both, in relation to the information they provide and to political time (honeymoon or lame duck time), which would suggest a channeling of issues differentiated by instruments, and a strategic behavior of the presidents.

${ }^{3}$ United Stated of América, Brazil and Turkey, but the latter two are recent members. 
Theoretically we use the information processing perspective (Jones, 2001; Jones, Sulkin, \& Larsen, 2003; Jones \& Baumgartner, 2005; Workman, 2015; Workman, Jones, \& Jochim, 2009) that helps us account for the double decisional process faced by the Colombian executive to combine the prioritization of policy issues with the instruments at its disposal. Deciding which policy issue to prioritize and which instrument to use involves processing information, and that information in the public sphere is often plentiful, and those responsible for processing it within the government have rational limitations of cognitive and institutional type (Jones, 2017; Simon, 1997). The way to manage the flow of information is through prioritization, that is, concentration of attention, which in turn is a scarce resource that implies that if it is assigned to some topics it is removed or diminished in others, finally indicating that the space in the agendas is limited.

This theoretical perspective predicts that governments are disproportionate information processors (Jones \& Baumgartner, 2005, p. 50), that they do not keep up with the speed at which this information appears, nor do they respond in relation to its importance, since institutional friction and their cognitive architectures impel them (and their staff) not to modify their dynamics of attention. That is, in principle they will minimize the signals from the environment and later when the information burden overwhelms, the response will be exaggerated. Major changes or disruptions within policies are often the result of disproportionate information processing.

From this perspective we assume presidents as strategic actors, prone to be rational but aware of the multiple restrictions that determine the construction and realization of their agendas. We focus on the factors that influence the prioritization of issues in Colombia. We start from the fact that there are some factors with high influence, which we group in three types, international, national, and personal. The first category includes the influence of the great powers, of the supranational scenarios in which the country participates, but also of globalization and international economic dynamics. The economy, it is predicted, will always be an important topic on the agendas.

National, which covers certain policies of the past, which are difficult to avoid and which are almost always on the agenda, also includes the "electoral campaign" factor and its context that determines that the candidates seek to differentiate themselves with innovative proposals, and that by Colombian institutional design, once elected they have to include in their development plans, and finally in the national category, are the legal and constitutional requirements that assign specific responsibilities to the presidents in various sectors. Finally, in the group of personal factors, there are ideological and partisan influences, and preferences, and interests of the president himself, as well as possible political commitments made, either in the campaign or with political groups which the president assumes personally, at certain times or by his own interests.

Regarding the assumptions associated with the prioritization of instruments, presidents process information from three broad perspectives: one associated with governability, which derives from having majorities in Congress and feeling supported by public opinion and by the most important economic and political sectors; another related to the political context and the specific policies they want to mobilize; and finally one with the institutional dynamics and responsibilities of the presidency. According to these assumptions, the president, for example, will prioritize instruments that are highly influenced by political time, an hypothesis that we will be able to partially verify in the end, for Colombia. 
Methodologically we use the data infrastructure of COL-PAP to make analysis of graphs and tables that provide the basic data to understand the distribution of attention, by sectors and instruments, and their interaction. The paper is divided into five parts, in the introduction we outline the main components of the text, secondly, we provide general elements for the understanding of the Colombian political system and the presidents we analyzed, then we presented the COL-PAP with an emphasis on the two instruments used. In section 4 we review the presidential attention dynamics, and finally we end up raising some lines of inquiry from the case presented and the COL-PAP databases.

\section{COLOMBIAN POLITICAL SYSTEM}

After 105 years Colombia had a new constitution in 1991, largely as a way out of an unprecedented crisis in political, social and institutional terms, which led the country to be considered a "dangerously weak" almost failed state (Kline, 2003; Rotberg, 2003). This change involved major adjustments in various dimensions of the institutional-political life, many of them of a modernizing and democratizing character. However, they have been merged with persistent elements such as violence, clientelism, and the permanence of regional and local powers with territorial, political and economic control, which, despite the dominant presidentialism, have sufficient capacity to influence either central decisions, or their implementation in the territories.

We use the three pillars of Cesar Gaviria's government (1990-1994) as an entry point for the recent evolution of the Colombian political system. Gaviria placed its main bets on three statements: pacifying Colombian life, modernizing institutions and strengthening the economy (El Tiempo, 1990). The first axis alluded to the fight against violence, a permanent imperative in Colombia. In addition to the bloody clashes linked to political parties, left-wing guerrillas flourished in the country from the 1960s and 1970s, then paramilitaries in the 1980s and 1990s, and together with both, the drug trafficking business developed, in which we are the world's top producer of cocaine (United Nations Office on Drugs and Crime [UNODC], 2019).

All Colombian governments since 1982 until today, have carried out peace efforts with various parties of the armed conflict. Along the way, agreements were reached with several important subversive groups, such as the M-19, the People's Liberation Army (EPL), and the Quintín Lame Armed Movement (MAQL). The Government of Pastrana (1998-2002) tried unsuccessfully with the FARC. More recently the governments of Uribe (2002-2010) and Santos (2010-2018) made positive progress against paramilitaries and guerrillas, achieving peace pacts in 2006 and 2016 respectively. However, huge challenges remain for the country's security, drug trafficking, National Liberation Guerrilla (ELN), FARC dissidents, and new criminal gangs.

The second axis refers to the "institutional shake-up", as Gaviria called it, which had its hopes focused on the redesign of the State that was implied in the new Constitution. This process materialized in several important areas, such as the creation of the Constitutional Court, and the public prosecutor's office, the establishment of the Tutela ${ }^{4}$, changes in states of exception, new mechanisms of citizen participation, reform of the Congress and the creation of the Vice-presidency, popular election of

\footnotetext{
4 "The tutela is an instrument created with the objective to guarantee a more expedite and inclusive judicial procedure to protect fundamental rights, by which any person without any qualified standing can ask any judge to protect their fundamental rights" (Corte Constitucional, 2019).
} 
governors (state level), establishment of an autonomous central bank, creation of the ombudsman's office, changes in the party system and deepening decentralization initiated in the 1980s, among others.

The 1991 Constitution opened the Pandora's box in the party system, from the traditional bipartisanship between liberals and conservatives, we moved to the partisan atomization that that reached 74 parties and movements in 2002 (Pérez, 2011). This led to the 2003 political reform that limited the formation of new parties and movements. This configured a new multi-party system with around ten political groupings, which has remained close to that number to this day, not without a significant level of fluidity, in which groups disappear and appear, and the names of some political movements are changed.

On executive-legislative relations, the 1991 Constitution sought to limit presidential power, strengthening Congress, and limiting the executive's powers of exception. However, little has been achieved, as presidential powers remain determinants of the political future in the country, and particularly in the formation of laws, although the recourse to states of exception has decreased considerably.

Gaviria's third axis was to strengthen the economy, with special emphasis on economic transformation and the productive revolution driven by his strategy known as "La Apertura". Since then, the Colombian economy has become more subject to market dynamics and less to pre-1990 state protectionism, which, while improving some economic indicators, has also deepened income inequality. The country is behind Brazil, which is the most unequal in Latin America (Organización de las Naciones Unidas [ONU] \& Comisión Económica para América Latina y el Caribe [CEPAL], 2019). In terms of Human Development Index, Colombia is 79th, with an HDI of 0.761 in the group of high human development countries (Programa de las Naciones Unidas para el Desarrollo [UNDP], 2019). The average unemployment rate is $10 \%$ in recent years (pre-pandemic), and GDP per capita is $\$ 6667$ USD.

Finally, the dynamics of public policies in the country can be summed up as a co-participation of the various branches of public power, with the executive's preponderance on the most important issues, and the Constitutional Court on rights issues. Presidents mainly act through bills, decrees, and CONPES, congressmen do it through bills and political control to the executive's functions, and the Constitutional Court with rulings, orders and constitutional reviews of laws and decrees.

\subsection{Uribe and Santos}

Box 1 presents relevant information on the two presidents discussed in this article. Between 2002 and 2010 Alvaro Uribe ruled, during two constitutional presidential terms. As seen in the third column, in his first period, he was elected with $54.52 \%$ in the first ballot. He was elected by the movement 'Primero Colombia', with a right-wing agenda. He had a majority in the Legislative Power, $61.7 \%$ in the Senate and 53.9\% in the House of Representatives (Duque, 2018). He reached 72\% approval at the start of his government and finished with $75 \%$. In the last column, government priorities are noted, with particular emphasis on the issue of security. For his second term, he won again in the first ballot with $62.35 \%$ of the votes. Given his popularity, his coalition in the legislative branch increased and his level of approval only slightly decreased. 
RAP | The Colombian Political Agendas Project: analysing presidential attention during the administrations of Uribe and Santos (2002-2018)

\begin{tabular}{|c|c|c|c|c|c|c|}
\hline & Period & $\begin{array}{c}\text { Number of } \\
\text { electoral votes }\end{array}$ & $\begin{array}{l}\text { Party - } \\
\text { ideology }\end{array}$ & $\begin{array}{l}\text { Coalition in } \\
\text { Congress }\end{array}$ & Approval & Government focus \\
\hline \multirow[t]{2}{*}{ Álvaro Uribe } & 2002-2006 & $\begin{array}{l}\text { He won in } 1 \text { st } \\
\text { ballot with } \\
54.52 \% \text {. The } \\
\text { second drew } \\
32.68 \%\end{array}$ & $\begin{array}{l}\text { Movement } \\
\text { Primero } \\
\text { Colombia. He } \\
\text { arrived with } \\
\text { a right-wing } \\
\text { agenda. }\end{array}$ & $\begin{array}{l}61.7 \% \text { in the } \\
\text { Senate, and } \\
53.9 \% \text { in } \\
\text { the House of } \\
\text { representatives }\end{array}$ & $\begin{array}{l}\text { Started at } \\
72 \% \text { ended at } \\
75 \%\end{array}$ & $\begin{array}{l}\text { Campaign slogan; } \\
\text { strong hand, big } \\
\text { heart. } \\
\text { Key policy: } \\
\text { democratic security }\end{array}$ \\
\hline & $2006-2010$ & $\begin{array}{l}\text { He won in } 1 \text { st } \\
\text { ballot with } \\
62.35 \% \text {. The } \\
\text { second drew } \\
22.02 \%\end{array}$ & $\begin{array}{l}\text { Primero } \\
\text { Colombia } \\
\text { in coalition. } \\
\text { He kept his } \\
\text { agenda. }\end{array}$ & $\begin{array}{l}68.6 \% \text { in the } \\
\text { Senate and } \\
67.4 \% \text { in } \\
\text { the House of } \\
\text { representatives }\end{array}$ & $\begin{array}{l}\text { Started at } \\
70 \% \text { ended at } \\
74 \%\end{array}$ & $\begin{array}{l}\text { Three little eggs: } \\
\text { democratic security, } \\
\text { social investment } \\
\text { and investor } \\
\text { confidence }\end{array}$ \\
\hline \multirow[t]{2}{*}{$\begin{array}{l}\text { Juan Manuel } \\
\text { Santos. }\end{array}$} & $2010-2014$ & $\begin{array}{l}\text { He won in } 2^{\text {nd }} \\
\text { ballot with } \\
69.1 \% \text {. The } \\
\text { second drew } \\
27.41 \%\end{array}$ & $\begin{array}{l}\text { U party. } \\
\text { Santos } \\
\text { influenced by } \\
\text { Third Way. }\end{array}$ & $\begin{array}{l}78.4 \% \text { in the } \\
\text { Senate, and } \\
84.2 \% \text { in } \\
\text { the House of } \\
\text { representatives }\end{array}$ & $\begin{array}{l}\text { Started at } \\
82 \% \text { ended at } \\
44 \%\end{array}$ & $\begin{array}{l}\text { Slogan, main } \\
\text { topics: Democratic } \\
\text { prosperity, keep } \\
\text { moving forward. Key } \\
\text { policies: job creation, } \\
\text { and peace process }\end{array}$ \\
\hline & 2014-2018 & $\begin{array}{l}\text { He won in 2nd } \\
\text { ballot with } \\
50.98 \% \text {. The } \\
\text { second drew } \\
44.98 \%\end{array}$ & $\begin{array}{l}\text { U party in } \\
\text { coalition. } \\
\text { He kept his } \\
\text { agenda. }\end{array}$ & $\begin{array}{l}69.61 \% \text { in the } \\
\text { Senate and } \\
71.08 \% \text { in } \\
\text { the House of } \\
\text { representatives }\end{array}$ & $\begin{array}{l}\text { Started at } \\
43 \% \text { ended at } \\
40 \%\end{array}$ & $\begin{array}{l}\text { Key policy: peace } \\
\text { process }\end{array}$ \\
\hline
\end{tabular}

Source: Elaborated by the authors.

Former President Juan Manuel Santos also ruled two terms, from 2010 to 2018. Like Uribe, he had his political origins in the traditional Liberal Party but came into government with coalitions. Contrary to his predecessor he always won in the second ballot, in the first period with $69.1 \%$ of the votes and, in the second, with 50.98\%. He came to power by the ' $U$ Party', previously created to support Uribe, yet, more personally, Santos has acknowledged having profound influences from the Third Way (Santos \& Blair, 1999). During his first term he had a great coalition in the legislative power with $78.4 \%$ in the Senate and $84.2 \%$ in the House of Representatives (Duque, 2018), which he largely managed to retain for his second government. In his first term he started with $82 \%$ approval and ended with $44 \%$, while in the second, and despite the peace agreement, which was his main priority, he ended with $40 \%$. 


\section{THE COLOMBIAN POLITICAL AGENDAS PROJECT}

As we stated in the introduction, COL-PAP has its main motivation in the study of Colombian presidentialism and the role of the president in the public policy process. With that in mind, the six databases shown in Box 2 have been built, using a codebook adapted to Colombian institutionality, but following the central guidelines of the CAP. Next, we take account of the construction of the Colombian codebook, the databases and explain what the bills and CONPES consist of.

\subsection{Codebook}

The CAP is based on a system of codes (See Box 2) applied to various indicators of public action by country and according to its content, seeking to ensure comparability and backward compatibility. Traditionally, the process of preparing the codebook by country and the codification process is done by teams working on research projects financed with public resources. In the Colombian case both processes have been at the head of a single person, a doctoral student, who has been creating the codebook in parallel with the coding.

First, three different codebooks (Spain, United States, and United Kingdom) were compared and an initial draft codebook was established, with which the coding of the bills' database began. Second, as observations that did not fit the draft codebook were identified, they were marked and sought again in the three codebooks mentioned. If no reference was found, they were highlighted and left pending for revision in the hope of finding new, similar observations. At the same time, modifications were made to the language according to the Colombian case.

Although the completed databases have been reviewed three times and although we try to adjust as much as possible to the CAP, we created and reorganized some topics. In particular, we propose the creation of a new major code, associated with the issue of internal conflict and peace processes, and 4 new sub-codes, on issues that we found difficult to locate according to the parameters of the codebooks consulted. However, it should be noted that these codes require discussion and harmonization with the CAP Master Codebook.

The topic of conflict and peace emerged among observations that did not fit well in the codes of justice (12) and defense (16), and given the centrality and relevance of the phenomenon to Colombia's political understanding over the past 60 years, we decided to propose it separately. The main criteria, in addition to the importance of the issue, was to make sure whether there were enough observations to account for the issue in the political agendas under construction. We created code number 50 (for no reason) but we are aware that once the Colombian codebook is harmonized with the CAP masterbook, we could relocate it, or even redistribute the observations it contains into the existing codes. In this code we include observations such as laws, bills and CONPES that respond to the dynamics of the conflict, but also the legislative and regulatory frameworks derived from the various peace processes that have occurred in the country. 


\begin{tabular}{|c|c|}
\hline \multicolumn{2}{|c|}{ Main Codes } \\
\hline 1. Macroeconomics & 13. Social Policy \\
\hline 2. Civil Rights, Minority Issues \& Civil Liberties & 14. Housing Issues and Community Development \\
\hline 3. Health & 15. Banking, Finance, and Domestic Commerce \\
\hline 4. Agriculture & 16. Defense \\
\hline 5. Labor and Employment & 17. Science, Technology and Communications \\
\hline 6. Education & 18. Foreign Trade \\
\hline 7. Environment & 19. International Affairs and Foreign Aid \\
\hline 8. Energy & 20. Government Operations \\
\hline 9. Immigration & 21. Public Lands and Indigenous Affairs \\
\hline 10. Transportation & 23. Culture \\
\hline 12. Justice, crime \& family & 50. Domestic Conflict and Peace Processes \\
\hline
\end{tabular}

Source: Elaborated by the authors.

The four sub-codes we propose are, 1214 for public notaries and registry, 1309 for children, adolescence, and youth, 1415 for home utilities services and 2016 for citizen participation mechanisms. In the process of debugging the observations with doubts, we found it difficult to locate these issues with certainty, which we temporarily solved by proposing new sub-codes, especially since they all have quite a few observations and are relevant in Colombian politics. For example, the issue of home utilities in Colombian legislation includes aqueduct, sewerage, toilet, electricity, gas, fixed telephony, among others. In addition, it has 126 observations in the database of bills.

\subsection{Databases}

COL-PAP currently has 6 databases, 5 completed and one in process, all covering at least the period of 1994-2018. Following the order in Box 3, we can see that the first one includes 2015 laws enacted between 1992 and 2020; the second includes 9883 bills between 1994 and 2018; the third, 818 Constitutional Reform Bills between 1994 and 2018, the fourth, the Constitutional Reforms between 1993 and 2019; the fifth, the CONPES between 1994 and 2019, and finally the media one, in development, which codifies articles from certain sections of 'Semana' magazine between 1994 and 2018. 


\begin{tabular}{|c|c|c|c|c|c|}
\hline Indicator & N & Time period & Source & Analysis units & Description \\
\hline Laws & 2015 & 01/1992- 01/2020 & Colombian Congress databases & Law & Decision \\
\hline Bills & 9883 & 07/1994-08/2018 & $\begin{array}{l}\text { - Colombian Congress databases } \\
\text { - Senate and House of } \\
\text { Representatives legislative } \\
\text { reports } \\
\text { - Congreso Visible Web }\end{array}$ & Bill & $\begin{array}{l}\text { Proposed } \\
\text { legislation }\end{array}$ \\
\hline $\begin{array}{l}\text { Constitutional } \\
\text { Reform Bills }\end{array}$ & 818 & 07/1994-08/2018 & Colombian Congress databases & $\begin{array}{l}\text { Constitutional } \\
\text { Reform Bills }\end{array}$ & $\begin{array}{l}\text { Proposed } \\
\text { legislation }\end{array}$ \\
\hline $\begin{array}{l}\text { Constitutional } \\
\text { Reforms }\end{array}$ & 53 & 08/1993-12/2019 & Colombian Congress databases & $\begin{array}{l}\text { Constitutional } \\
\text { Reforms }\end{array}$ & Decision \\
\hline CONPES & 1407 & 01/1994-01/2019 & $\begin{array}{l}\text { National Development } \\
\text { Department databases }\end{array}$ & CONPES & Decision \\
\hline Media & $\begin{array}{l}\text { Near } \\
30000\end{array}$ & 01/1994-08/2018 & Semana Magazine web & Article & $\begin{array}{c}\text { Articles by their } \\
\text { content }\end{array}$ \\
\hline Total & 44176 & & & & \\
\hline
\end{tabular}

Source: Elaborated by the authors.

For this paper, we extracted from the databases of bills and CONPES those corresponding to the Uribe and Santos governments, 829 and 839 respectively. In the following subtitle we delve into and compare these two instruments. We put special emphasis on the CONPES, which are a distinctive type of document of the Colombian case, without reference within the existing CAP databases. Finally, we justify the choice of the period chosen for the analysis.

\subsection{Bills and CONPES}

Bills are legislative proposals addressed to the Congress, submitted by various people or entities that constitutionally have legislative initiative. Unlike the USA case, not only congressmen have legislative initiative in Colombia, there are also eleven other sources of bills, including the executive through its ministers, citizens through popular initiative, and some national entities on issues of their competence.

However, production of bills is concentrated in the executive and legislative branches. Between January 1992 and January 2020, 2015 laws were enacted, of which $98.2 \%$ come from bills originating in both institutions, or from their collaboration with other entities. Of the 2015 laws mentioned, the 
executive originated $46.7 \%$, and the legislature $51.5 \%$ (COL-PAP data). Bills may become ordinary laws, framework laws, statutory laws, laws approving international treaties, organic laws, or constitutional reforms when their intention is to modify the Constitution.

The acronym CONPES, which stands for National Council for Economic and Social Policy, refers to an intergovernmental coordination mechanism within the executive branch and the documents it produces. It is not a sectoral entity nor does it have its own legal status, but a coordination mechanism headed by the president, with the central participation of his ministerial cabinet, and with the technical secretariat of the National Planning Department, the most technical entity of the government, which is responsible for leading the development of the CONPES documents. The Planning Department produces planning and advice guidelines for the government in economic and social policy within the Colombian State. In addition to the development of CONPES, this coordination mechanism has other important functions, including the preparation of the National Development Plan ${ }^{5}$, and the annual macroeconomic programming.

\section{BOX 4 BILLS AND CONPES COMPARED}

\begin{tabular}{|c|c|c|c|c|}
\hline & Definition & Initiative & Process & Legally Binding \\
\hline Bills & $\begin{array}{l}\text { They are legislative } \\
\text { proposals }\end{array}$ & $\begin{array}{l}\text { In Colombia there are } 12 \text { sources of bills, } \\
\text { but those presented by Congress and the } \\
\text { executive prevail }\end{array}$ & $\begin{array}{l}\text { Mediated by } \\
\text { Congress }\end{array}$ & $\begin{array}{l}\text { Once they } \\
\text { become laws }\end{array}$ \\
\hline CONPES & $\begin{array}{l}\text { They are decisions from } \\
\text { the executive branch }\end{array}$ & $\begin{array}{l}\text { They arise within the government itself, } \\
\text { are processed and led by the DNP and } \\
\text { approved by the CONPES }\end{array}$ & Unilateral & $\begin{array}{l}\text { They guide } \\
\text { the activity of } \\
\text { the executive } \\
\text { branch }\end{array}$ \\
\hline
\end{tabular}

Source: Elaborated by the authors.

CONPES documents are political decisions that articulate various entities in the executive branch to achieve objectives primarily defined by the president-in-office, mostly linked to the development plan. They are not decrees, nor do they resemble bills, or any other legal document within the Colombian State. They have no external control other than the executive itself to account for their rationality, monitoring, implementation, and usefulness, so they can be referred to as unilateral. This is largely because the CONPES is a consultative body and its decisions (the CONPES documents) are not legally binding on the government itself, as the Constitutional Court has said (Sentencia C-105 de 2016, 2016).

\footnotetext{
${ }^{5}$ The National Development Plan is the road map of each government. It contains national and sectoral objectives and targets for State action in the medium and long term, the economic, social and environmental strategies and policies that will guide the Government's action; the intergovernmental coordination mechanisms; and concrete proposals on how to achieve the proposed objectives with the appropriate budgetary support. See Law 152 of 1994.
} 
However, in Colombian presidential system, CONPES are backed by the authority emanating from the president, which largely binds other entities and local governments, although it is also true that there are examples of symbolic CONPES, without support in a real willingness of the government to change the problematic circumstances that inspired them.

Nor are they a single type of document; there are strategic, public policy, credit management, and procedural documents, among others. More specifically according to its titles we find CONPES of loan approval, favorable concepts, declaration of strategic importance, distribution of profits of public companies, public policy guidelines, approval of policies, among others. As we will see later, like bills, they are issued in almost all sectors of the State, suggesting that they are a well-established public policy instrument widely used by governments, and as shown below, in some governments they exceed the number of bills.

The studied period includes 16 years (2002-2018), in which two presidents ruled consecutively and uninterruptedly for eight years each, constituting an unprecedented fact in the 200 years of the country's republican life. This was made possible by the approval of the immediate re-election during the first government of Alvaro Uribe, a decision that would later be eliminated by his successor Juan Manuel Santos, to return to the game rules prior to 2002. It should also be noted that during this period the state successfully struck and forced negotiations with the FARC guerrillas, the oldest in the country.

\section{THE DYNAMICS OF PRESIDENTIAL ATTENTION}

In this section we show the exploratory analysis in three parts. The first has to do with the prioritization of policy issues, the second with the distribution of attention to the two proposed instruments, and the third relates the first two, with a view to exploring the confirmation of the initial hypothesis that there is indeed a differentiated channelling of policy issues between instruments, and strategic use of them, and which issues are prioritized by each.

\subsection{Presidential attention to policy issues}

In this section we show the dynamics of presidential prioritization of policy issues in two different ways, first the aggregate numbers, and second the dynamics by sector over time. Figure 1 shows the distribution of attention by sector, according to the aggregate number of bills. Figure 2 does the same with the CONPES. In both we see the dynamics of attention for the 22 sectors analysed, and the two presidents. In the two graphs we highlight only the seven largest sectors in bills and CONPES, and the differences between presidents. 
$\%$ bills by sector and by president
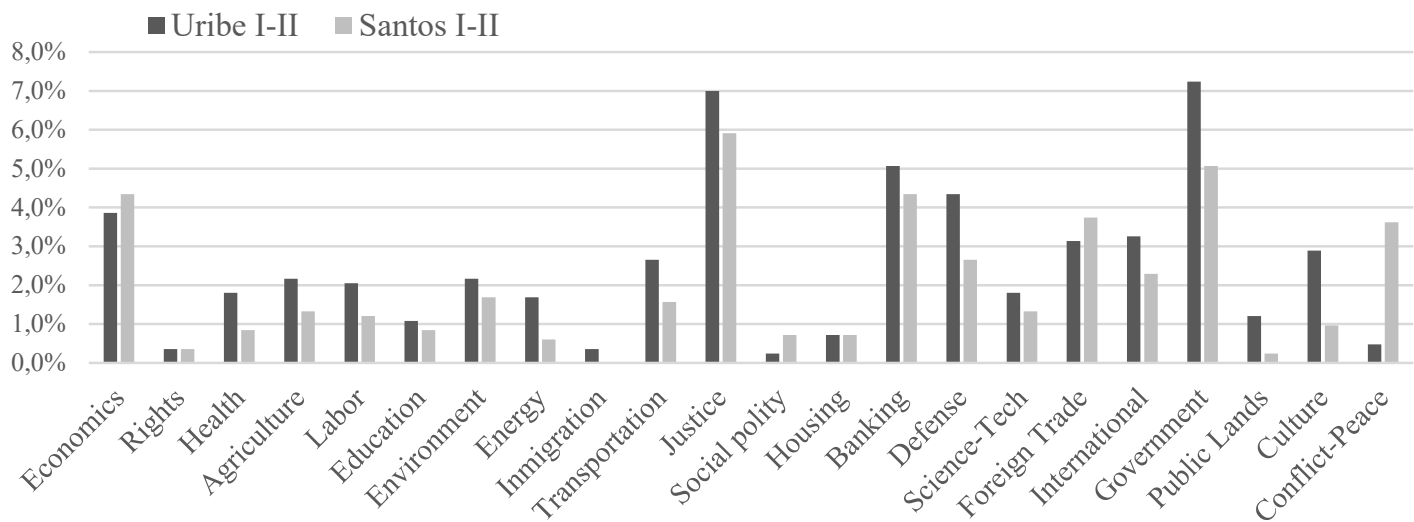

Source: Elaborated by the authors.

In descending order in terms of bills, Uribe has the highest numbers in government, justice, banking and domestic commerce, and defense, economy, culture, and transport. While through CONPES he prioritized government, transportation, economy, housing, energy, education, and agriculture. This begins to show two important observations, the prevalence of common themes, government, economy, and transport, but also the existence of diverse themes among instruments that already suggest a differentiated use of them, and possibly the existence of themes with their personal stamp.

From Santos' side, the issues with the highest number of bills are justice, government, economy, banking and domestic trade, foreign trade, conflict and peace, and defense. While through CONPES it has the largest numbers in government, transportation, economy, education, conflict and peace, social welfare, and housing. As in Uribe, Santos also has common themes between instruments, government, economy, and conflict and peace, and different themes.

FIGURE 2 CONPES: AVERAGE PRESIDENTIAL ATTENTION BY SECTOR

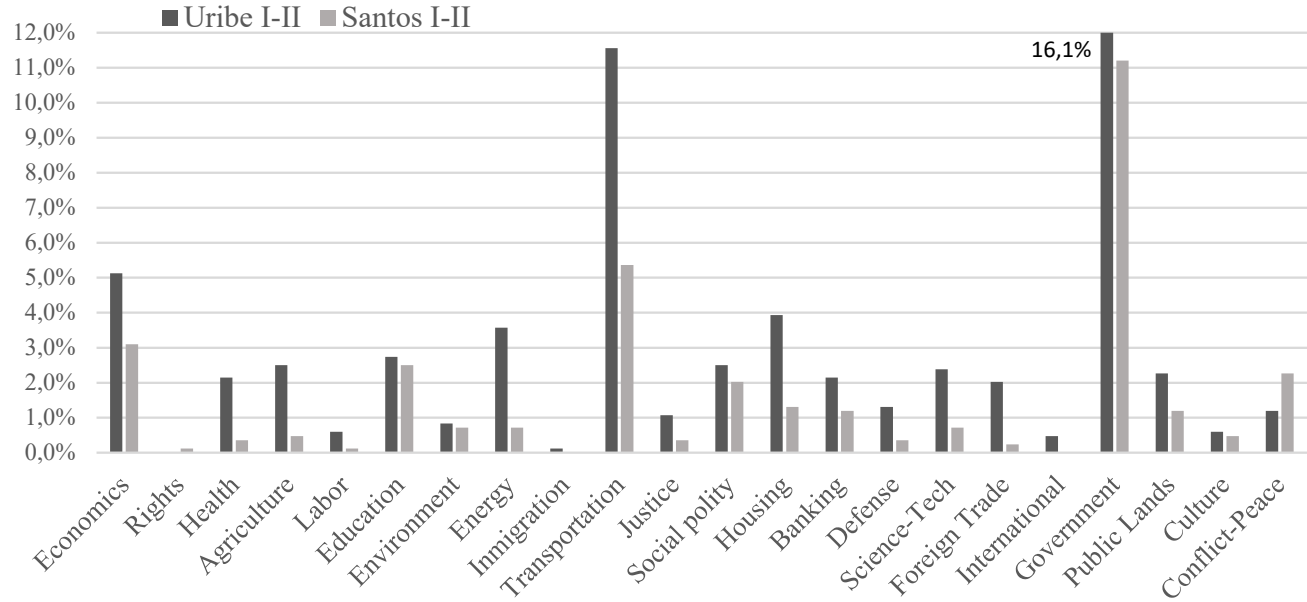

Source: Elaborated by the authors. 
As we saw in the theoretical discussion, it is quite possible that the presidential agenda privileges some issues over others. Presidents are expected to address issues that are constitutionally and legally binding on them, as well as economic issues, but the agenda is also expected to have their own stamp. These two expectations seem to be confirmed by Uribe's and Santos' use of bills, with government and economic issues appearing in the highest percentages in both presidents.

Among the other issues, the personal stamp also stands out. In Uribe's case, as we saw before (Box 1), his main priority was democratic security, and this is reflected in the prevalence of the defence sector among the bills, which does not appear, for example, in Santos, who, on the contrary, privileged the policy of peace through dialogue, which is reflected in both bills and CONPES. In Santos' case, his attention to peace is evident in the two instruments.

If we add the data from the two instruments and from the two presidents, as shown in Figure 3, we corroborate the presidential concentration on a few issues, 5 topics (out of 22 ) that represent $52.1 \%$ of the total observations. The Colombian case follows previous findings that suggest that there are certain topics that are the ones that receive the most observations (Borghetto et al., 2017; Breeman et al., 2009; Jennings et al., 2011). Borghetto and company highlight economics, government operations, justice and foreign policy, the latter being the only issue that does not appear for the Colombian case. Furthermore, they claim that economy and government operations combined account for at least $20 \%$ of the total agenda, a claim confirmed in Colombia where these two issues occupy $28 \%$.

FIGURE 3 PRESIDENTIAL ATTENTION BY ADDING THE TWO INSTRUMENTS AND THE TWO PRESIDENTS

Classification after adding bills and CONPES

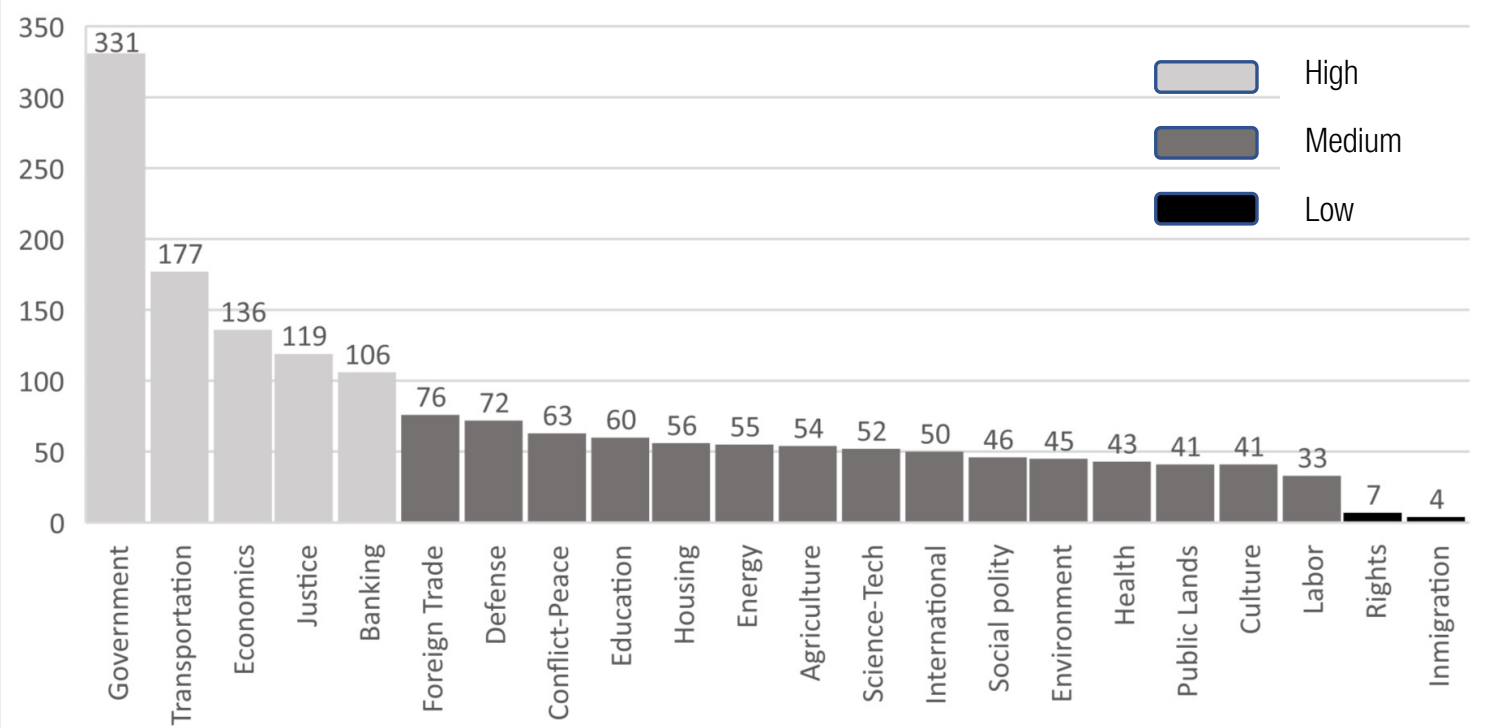

Source: Elaborated by the authors. 
The less numerous are civil rights and immigration, which together account for only $0.6 \%$ of the total of the 1668 observations. The first has been largely assumed by the Constitutional Court, and the second is an issue that until 2018 was not a problem worthy of greater attention. Finally, there is the middle level for the remaining topics, 15 out of 22, which are in a range of 33 to 76 observations when adding up both documents. Here we find the topics of social policy, defense and peace, and employment, among others. This distribution is important since it indicates a certain regularity in the dynamics of presidential attention to most public issues. As suggested in the introduction, there are many issues that governments need to address, most of which are precedents, perhaps not priorities, but should be on the agenda. Next, we see the dynamics of attention across time by sector.

Figure 4 shows the dynamics for 20 topics (those with more than 10 observations). Individual graphs indicate relative attention with respect to total observations. It shows that very few have similar behaviors between instruments, and that most have concentration of observations in some years, either for both instruments, or for one of the two. It should be noted here that the numbers suggest attention but do not confirm it.

\section{FIGURE 4 PERCENTAGE OF ATTENTION ACROSS ISSUES AND INSTRUMENTS}

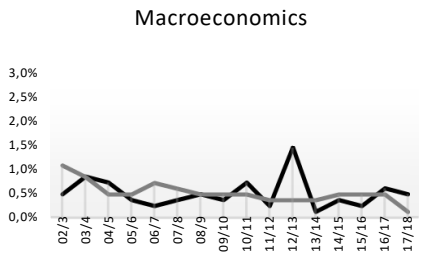

Labor \& employment

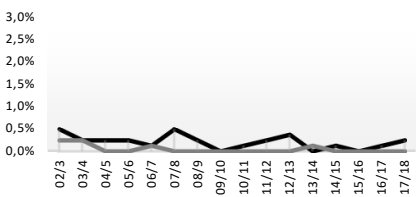

Energy

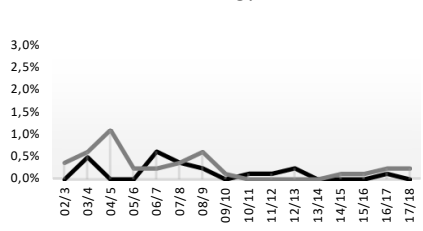

Social Policy

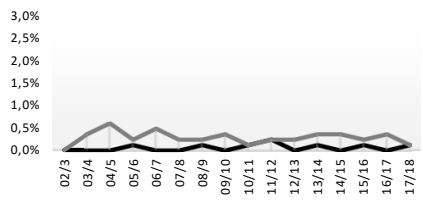

Health

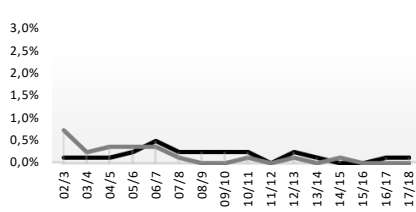

Education

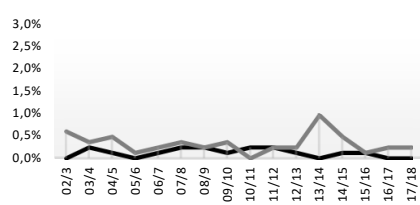

Transportation

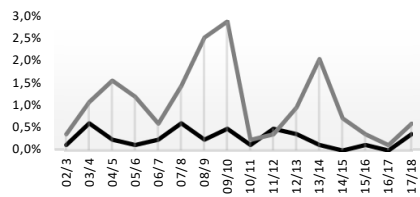

Housing

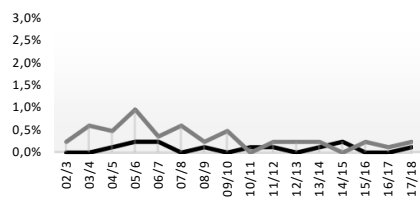

Agriculture

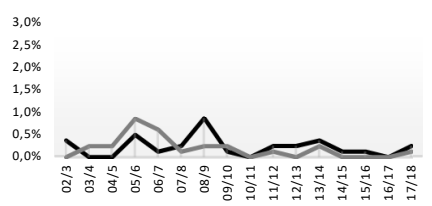

Environment

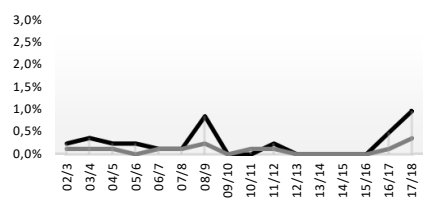

Crime, Justice, Family

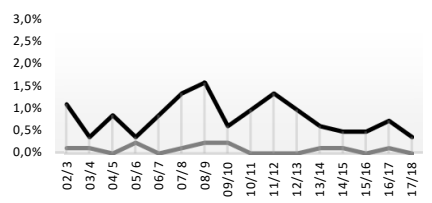

Banking, Commerce

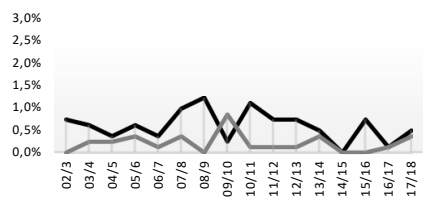




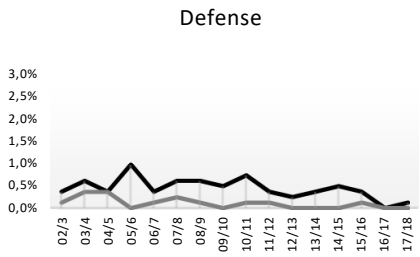

International Affairs

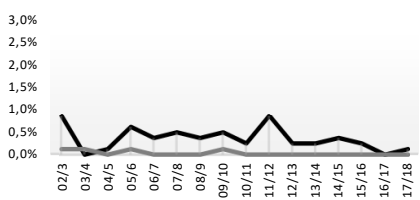

Public Lands \& Indigenous Affairs

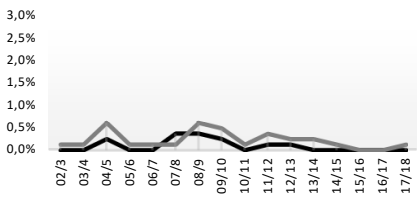

Science, Technology

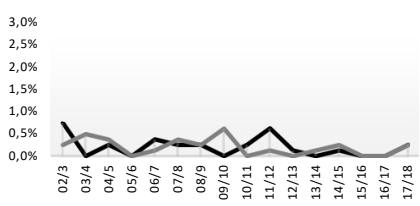

Government Operations

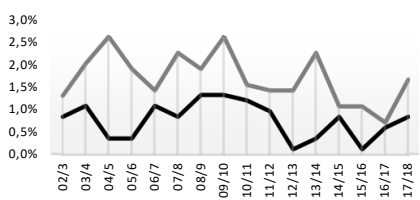

Domestic conflic \& Peace processes

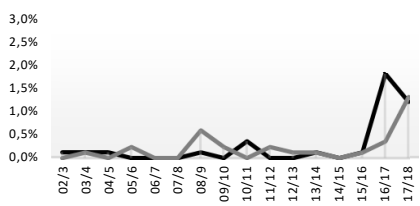

Foreign Trade

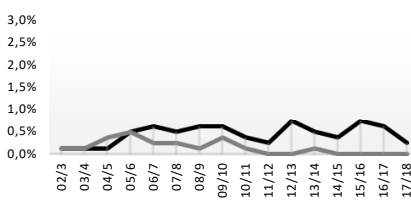

Culture
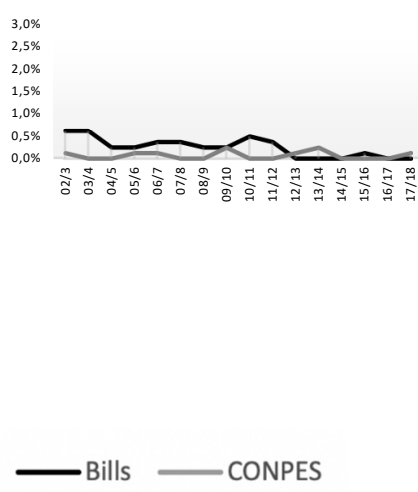

Source: Elaborated by the authors.

As seen in Figure 4 there are 12 topics that have peaks greater than or close to $1 \%$ at some point, this is more than 10 items per year. Do these junctures constitute increased attention or public policy punctuations? As John and Bevan argue (2012, p. 90) this can only be known "with a better explanation of the causal processes that act at each critical juncture."

If we review the 5 sectors mentioned above we see that, although the numbers are higher for Uribe, a relative distribution is maintained between half and half of the period, with the exception of economy that has a peak in the first period of Santos. Among the other sectors we can create two groups, the most similar in distribution over time, which move around $0.5 \%$ (health, employment, social welfare, science and technology, public lands and culture), and the remaining that have a peak in one of the two documents or in both.

Finally let us take a look at one example of information processing and trade-offs. Defense was Uribe's priority, and it diminished in Santos, who clearly had peace as a higher priority. Here is a double example of information processing, the one that led Uribe to offer war in the face of the failed peace process between Pastrana and the FARC, and the one that led Santos to prioritize peace in the face of his reading that the FARC was ready to negotiate. This same example, besides showing the change of emphasis from one government to another, shows within the Santos administration how the peace effort implies a decrease in attention to defence and other important sectors.

\subsection{Presidential use of instruments}

Figure 5 summarizes the basic numbers for the two types of instruments analyzed, by year and by presidential term. The first consideration relates to the similarity of the total numbers between the two documents: 829 bills and 839 CONPES, for a total of 1668 observations, an average of 104 per year. Both are used to influence all sectors, privileging in number, some topics by bills and others by 
CONPES as we will see later. Along with the decrees ${ }^{6}$, and from a formal point of view, these three documents are the main mode of presidential intervention in public policy.

\section{FIGURE 5 BILLS AND CONPES BY YEAR}

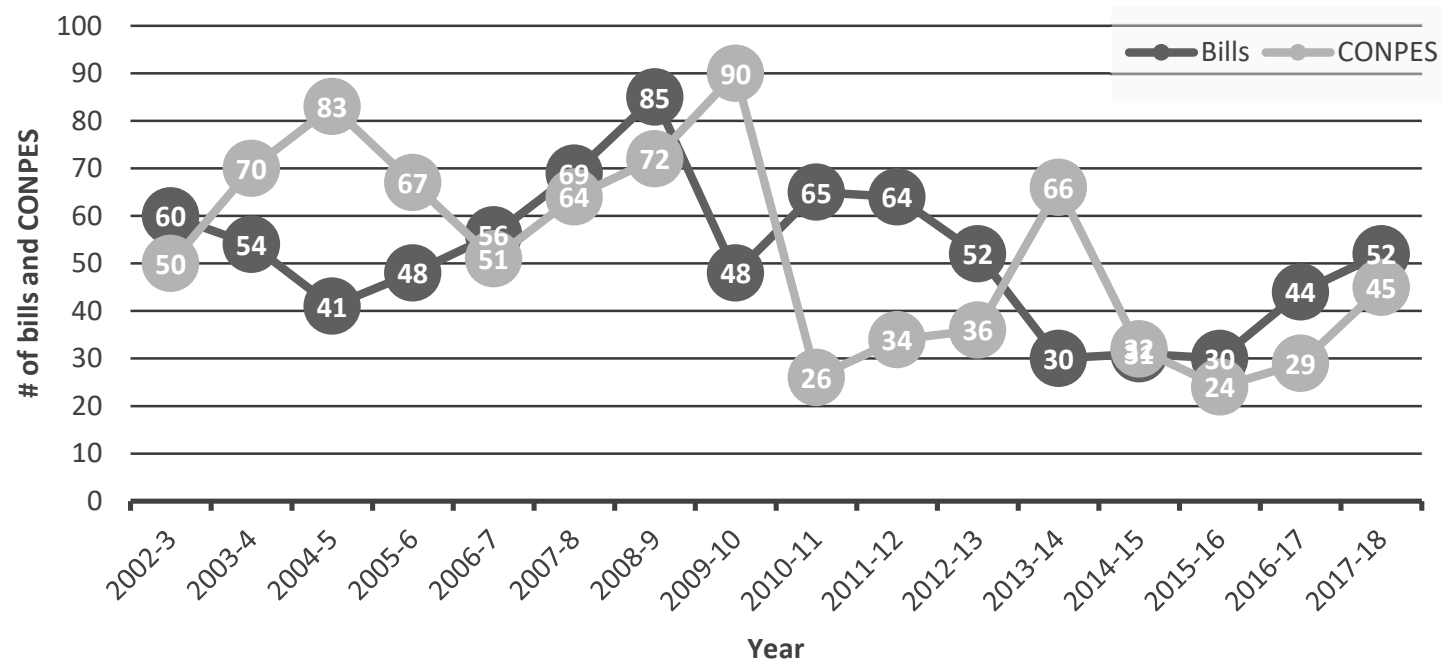

Source: Elaborated by the authors.

There is also an important difference between the two periods of Uribe and the two of Santos, showing that the former was much more active in both instruments, compared to the second. Uribe presented 461 bills (203 for his first term and 258 for the second) and 547 CONPES (270 and 277), while Santos had 368 (211 and 157) and 292 (162 and 130) respectively. Here it is valid to remember the hypothesis that suggests that presidents who have a lot of public support, and Uribe had it, are more likely to use unilateral instruments. This is a clear derivation from information theory, which, although we cannot prove it, is suggested for further research.

Given the interest in exploring presidential strategic behavior when presidents channel its priorities through one or another instrument, it seems suggestive that the attention between instruments is similar for the most part of the period studied. There are four moments of divergence, the first between 2004 and 2005, when the CONPES predominated, the second in 2009 and 2010, again with CONPES on top, the third between 2010 and 2011 with considerable primacy of bills, and the last in 2013-2014 where CONPES again prevailed.

Another relevant observation, suggested in Figure 5, is that the CONPES tend to be more numerous at the end of each term, when presidents tend to have less political capital and the support of Congress declines, while bills tend to be more numerous at the beginning of government. This suggests that presidents weigh up the use of one instrument or another, using context and instrument information,

${ }^{6}$ In Colombia there are various types of decrees, the most numerous are ordinary and regulatory. The former are mostly routine, while the latter specify laws and create implementation frameworks. 
according to political variables such as political timing, which influences the prioritization of issues through them.

\subsection{The channelization of policy issues through instruments}

Finally, we review the strategic channeling of issues according to the two instruments. Each instrument offers different information and its own structure of opportunity that affects the allocation of attention to policy issues (Larsen-Price, 2012). Therefore, each type of document is an intervention channel that can be used strategically by the president according to the information he has about the policies, the political process, and each of the instruments.

Box 5 takes the numbers for each sector distributed in bills and CONPES to construct a classification of four channeling types. In the first type are those with the least observations, rights, and immigration. In the second, there are five topics in which the numbers are very similar between bills and CONPES. In the third, there are eight topics in which the bills predominate, and in the last, seven with significant predominance of CONPES. That is, 15 out of 22 topics, which group $78 \%$ of the total observations, are channeled with significant differences through one document over another. Obviously, we do not conclude that this dominance is always substantial, but it does suggest further research, particularly on the role of CONPES in seven such important sectors.

BOX 5 TOPICS BY TYPE OF CHANNELING

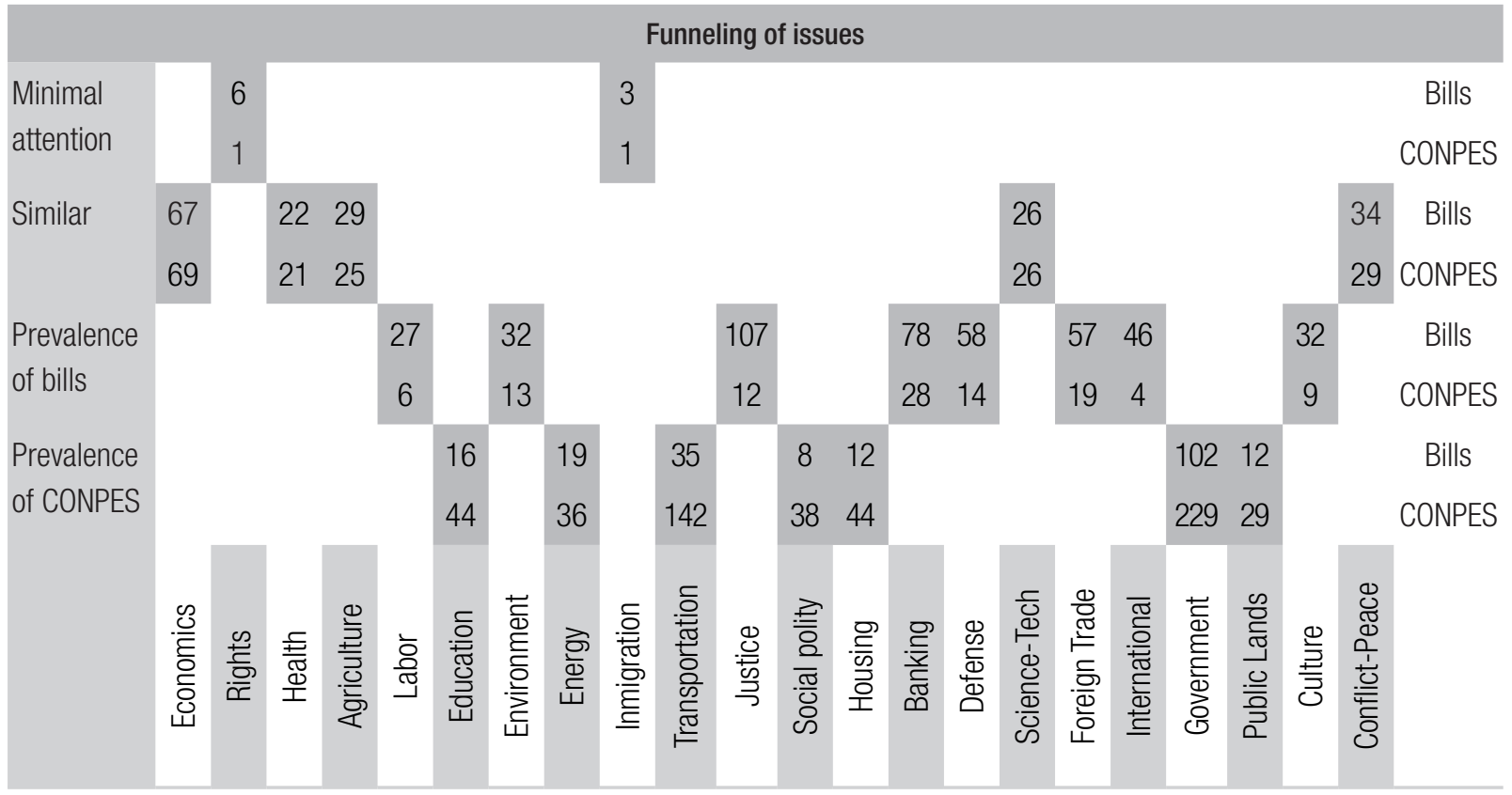

Source: Elaborated by the authors. 
About channeling types, we have already mentioned why civil rights and migration issues are the least addressed. In relation to the second, while all are important issues for state management and the contribution of the executive to them is key, the macroeconomic issue stands out, for its numbers, even though the 1991 Constitution delegated key economic policy responsibilities to the Central Bank (Cárdenas \& Pachón, 2010).

The types three and four together constitute 15 of the 22 topics analyzed, demonstrating the importance of the analysis of presidential political attention, not only by sector, but through the channels used by the executive. In eight topics, the analysis of bills is decisive for the realization of the respective policies, while in seven CONPES are decisive, which has been a policy instrument traditionally undervalued by the Colombian academia. We emphasize that through CONPES the numbers are greater particularly in certain types of issues: education, energy, transportation, housing, united by the particularity that they are CONPES that involve either allocation of resources, or specific infrastructure, which is usually in charge of the executive.

\section{FROM THE COLOMBIAN CASE TO COMPARISON: FUTURE RESEARCH}

The full map of presidential attention is an elusive aspiration, yet the CAP provides perhaps the most rigorous and promising set of tools in that regard at present. It is very likely that we will be able to partially reconstruct it through the analysis of policy issues and the tools that governments prioritize. In this article we have approached two of the most important ones for Colombia, CONPES and bills, through which the executive has a significant impact on the substance of policies. We have shown some COL-PAP data suggesting that the joint analysis of policy issue prioritization by various instruments extends our understanding of presidential attention dynamics to a broader level than separate or single-instrument analysis provides.

This first approximation is not only suggestive in itself, but together with the data infrastructure of the COL-PAP, it opens up important research possibilities, both for the analysis of the policy process and the Colombian political systems, and of these in comparative perspective. In relation to the case we have presented, we need to refine research designs and questions and continue to shape what should be an interdisciplinary research agenda around COL-PAP data applied to sectoral and institutional analysis.

In relation to the presidential agenda, it would be interesting to investigate institutional determinants such as the type of presidentialism, the weakness of Congress, and the fragmentation and volatility of the party system. In this article we have highlighted some aspects that suggest the verification of important theoretical aspects, for example that the instruments offer various possibilities of channelling presidential attention to issues, or that the theory of interrupted equilibrium is fulfilled in the sectoral dynamics, which gives rise to the proposal of further research to verify these initial findings.

The analysis of presidential attention should be extended to attention in other institutions, such as Congress, and its interaction with society and the media. This requires us to increase databases, debug them, and harmonize them with the CAP. The analysis of sectoral and institutional dynamics, the study of interactions between agendas should be at the heart of the COL-PAP agenda. 
From a theoretical point of view, we have two clear paths, on the one hand there is the option of testing in Colombia the Punctuated Equilibrium Theory, and the Information Processing Perspective, highly used by the CAP community, although we are clear that the CAP is united by data and not by theory (Baumgartner, Breunig, \& Grossman, 2019b; Green-Pedersen \& Walgrave, 2014). And on the other hand, precisely the theoretical openness of the CAP allows us to work in a quite underdeveloped area in Colombia and Latin America: theoretical innovation. We need to think more deeply and develop our own frameworks and theories.

Finally, there is the comparative perspective at the Latin American and global levels. We have the possibility, together with the Brazilian project, to start building a research agenda that allows not only to expand the CAP to other countries (Mexico, Ecuador, Guatemala where there are people interested), but to outline some common questions, according to the shared context, enabling us to analyze for example presidentialism, the logics of patronage or institutional fragility, and other aspects more or less typical of the region.

At all levels, whether within Colombia or at the Latin American level, we have the opportunity to implement the broad agenda of the CAP at the intercontinental level, which extends from traditional sectoral analyses or attention dynamics in institutions such as congresses or executives, to media analysis, social movements, political parties, policy responsiveness and the quality of democracy, among other emerging agendas (Baumgartner, Breunig, \& Grossman, 2019a). At the same time the established CAP will have the opportunity to broaden its horizons to the second Latin American national case, with very interesting particularities that provide the possibility to prove very established assumptions within the CAP community in a very different context to those already analyzed. 


\section{REFERENCES}

Aranda-Jan, A. C. (2018). Understanding the nature of presidential policymaking in Mexico through an agenda-setting approach (Doctoral Dissertation). University of Southampton, Southampton, UK. Retrieved from https://eprints.soton.ac.uk/427729/1/ ThesisFinal26112018.pdf

Baumgartner, F. R., Breunig, C., \& Grossman, E. (Eds.). (2019a). Comparative Policy Agendas: Theory, Tools, Data. Oxford, UK: Oxford University Press.

Baumgartner, F. R., Breunig, C., \& Grossman, E. (2019b). The Comparative Agendas Project: Intellectual Roots and Current Developments. In F. R. Baumgartner, C. Breunig, \& E. Grossman. (Eds.), Comparative Policy Agendas: Theory, Tools, Data. Oxford, UK: Oxford University Press.

Baumgartner, F. R., Brouard, S., \& Grossman, E. (2009). Agenda-setting dynamics in France: Revisiting the 'partisan hypothesis'. French Politics, 7(2), 75-95. Retrieved from https://doi.org/10.1057/ fp. 2009.7

Bevan, S. (2019). Gone Fishing: The Creation of the Comparative Agendas Project Master Codebook. In F. R. Baumgartner, C. Breunig, \& E. Grossman. (Eds.), Comparative Policy Agendas: Theory, Tools, Data. Oxford, UK: Oxford University Press.

Borghetto, E., Visconti, F., \& Michieli, M. (2017). Government Agenda-Setting in Italian Coalitions. Testing the «Partisan Hypothesis» Using Italian Investiture Speeches 1979- 2014. Rivista Italiana di Politiche Pubbliche, 2, 193-220. Retrieved from https://doi.org/10.1483/87214

Brasil, F., Capella, A. C. N., \& Fagan, E. J. (2020). Policy Change in Brazil: New Challenges for Policy Analysis in Latin America. Latin American Policy, 11(1), 24-41. Retrieved from https://doi.org/10.1111/ lamp. 12178

Breeman, G., Lowery, D., Poppelaars, C., Resodihardjo, S. L., Timmermans, A., \& de Vries, J. (2009). Political Attention in a Coalition System: Analysing Queen's Speeches in the Netherlands 1945-2007. Acta Politica, 44(1), 1-27. Retrieved from https://doi.org/10.1057/ap.2008.16

Cárdenas, M., \& Pachón, M. (2010). Cómo la Constitución de 1991 cambió los procesos de formulación de las políticas públicas. In E. Lora, \&
C. Scartascini. (Eds.), Consecuencias imprevistas de la Constitución de 1991: La influencia de la política en las políticas económicas (1a ed., pp. 22-58). Bogotá, Colômbia: Fedesarrollo.

Cheibub-Figueiredo, A., Pérez-Liñán, A., \& Martins-Vieira, M. (2009). Political and Institutional Determinants of the executive's Legislative success in Latin america. Brazilian Political Science Review, 3(2), 155-171.

Corte Constitucional. (2019). Colombian Constitutional Court on: HIV criminalization, sex work, abortion, same sex marriage and drugs. Retrieved from https://www.corteconstitucional. gov.co/english/Cartilla\%20minor\%C3\%ADas\%20 2019.pdf

Dowding, K., Hindmoor, A., Iles, R., \& John, P. (2010). Policy Agendas in Australian Politics: The Governor-General's Speeches, 1945-2008. Australian Journal of Political Science, 45(4), 533-557. Retrieved from https://doi.org/10.1080/10361146.2010.517174

Duque, J. (2018). Presidencialismo de transacción. Cambio institucional, coaliciones y clientelismo 20022016 (1a ed., vol. 2). Universidad del Valle.

Eissler, R. (2016). The Priorities of a President: Understanding Presidential Policy Attention and Prioritization. In Proceeding of 2016 Annual meeting of the Comparative Agendas Project, Geneva, Switzerland.

Eissler, R. (2018). Prioritizer-in-Chief: The Role of the President in the Policy Process from Reagan to Obama (Doctoral Dissertation). Univerity of Texas, Austin, TX.

El Tiempo. (1990, August 8). La Paz del país es mi reto histórico. Retrieved from www.eltiempo.com/ archivo/documento/MAM-70117

Green-Pedersen, C., \& Walgrave, S. (2014). Political Agenda Setting: An Approach to Studying Political Systems. In C. Green-Pedersen, \& S. Walgrave. (Eds.), Agenda Setting, Policies and Political Systems: A Comparative Approach (1a ed., pp. 1-18). Chicago, IL: University of Chicago Press.

Jennings, W., Bevan, S., \& John, P. (2011). The Agenda of British Government: The Speech from the Throne, 1911-2008. Political Studies, 59, 74-98.

John, P., \& Bevan, S. (2012). What are policy punctuations? Large changes in the legislative agenda 
of the UK Government, 1911-2008. Policy Studies Journal, 40(1), 89-108.

Jones, B. D. (2001). Politics and the Architecture of Choice: Bounded Rationality and Governance (1a ed.). Chicago, IL: University of Chicago Press.

Jones, B. D. (2017). Behavioral rationality as a foundation for public policy studies. Cognitive Systems Research, 43, 63-75. Retrieved from https:// doi.org/10.1016/j.cogsys.2017.01.003

Jones, B. D., \& Baumgartner, F. R. (2005). The Politics of Attention: How Government Prioritizes Problems (1a ed.). Chicago, IL: University of Chicago Press.

Jones, B. D., Sulkin, T., \& Larsen, H. A. (2003). Policy punctuations in American political institutions. American Political Science Review, 97(01), 151-169.

Jones, C. O. (2005). The presidency in a separated system (2nd ed). Washington, DC: Brookings Institution Press.

Kline, H. F. (2003). Colombia: Lawlessness, Drug Trafficking, and Carving Up the State. En State failure and state weakness in a time of terror (1a ed., pp. 161182). Washington, DC: Brookings Institution Press.

Larsen-Price, H. A. (2012). The right tool for the job: The canalization of presidential policy attention by policy instrument. Policy Studies Journal, 40(1), $147-168$

Mance, H. (2006). The politics of sustainability: The rise and decline of the Colombian ministry of environment (Master Thesis). Oxford University, Oxford, UK.

Mortensen, P. B., Green-Pedersen, C., Breeman, G., Chaqués-Bonafont, L., Jennings, W., John, P., Palau, A. M., \& Timmermans, A. (2011). Comparing Government Agendas: Executive Speeches in the Netherlands, United Kingdom, and Denmark. Comparative Political Studies, 44(8), 973-1000. Retrieved from https://doi. org/10.1177/0010414011405162

Organización de las Naciones Unidas \& Comisión Económica para América Latina y el Caribe. (2019). Panorama social de América Latina 2019. Santiago, Chile: Author.
Pérez, N. J. (2011). El sistema de partidos colombiano hoy. Partidos y representación en el Congreso después de la reforma de 2003. Opera, 11, 71-84.

Rodríguez, M. (2007). La política ambiental en el proyecto del "Plan Nacional de Desarrollo 20062010". Boletín Ecofondo, 36-43.

Rotberg, R. I. (Ed.). (2003). State failure and state weakness in a time of terror. Washington, DC: Brookings Institution Press.

Santos, J. M., \& Blair, T. (1999). La tercera vía, una alternativa para Colombia (1a ed.). Madrid, Spain; Aguilar.

Santos, M. L., Pérez-Liñán, A., \& García Montero, M. (2014). El control presidencial de la agenda legislativa en América Latina. Revista de Ciencia Política (Santiago), 34(3), 511-536. Retrieved from https://doi.org/10.4067/S0718-090X2014000300001

Sentencia C-105 de marzo de 2016. (2016). Colombia, Bogota, Corte Institucional.

Simon, H. A. (1997). Administrative behavior: A study of decision-making processes in administrative organizations (4th ed). New York, NY: Macmillan.

Programa de las Naciones Unidas para el Desarrollo. (2019). Informe sobre Desarrollo Humano 2019 Más allá del ingreso, más allá de los promedios, más allá del presente: Desigualdades del desarrollo humano en el siglo XXI. New York, NY: Author.

United Nations Office on Drugs and Crime. (2019). World drug report 2019. Vienna, Austria: Author.

Walgrave, S., \& Boydstun, A.E. (2019). The Comparative Agendas Project: The Evolving Research Interests and Designs of the CAP Scholarly Community. En Comparative Policy Agendas: Theory, Tools, Data (1a ed.). Oxford, UK: Oxford University Press.

Workman, S. (2015). The dynamics of bureaucracy in the US government: How Congress and federal agencies process information and solve problems. Cambridge, UK: Cambridge University Press.

Workman, S., Jones, B. D., \& Jochim, A. E. (2009). Information processing and policy dynamics. Policy Studies Journal, 37(1), 75-92. 


\section{Juan Guillermo Vieira Silva}

https://orcid.org/0000-0002-7613-3729

Advanced graduate student (finishing the doctoral dissertation) of the Ph.D. program in political studies and international relations at the Universidad Nacional de Colombia; Professor of public policy at Universidad Autónoma de Manizales, Department of Political and Legal Sciences. E-mail: jvieira@autonoma.edu.co

\section{Jeraldine Alicia del Cid Castro}

https://orcid.org/0000-0002-8318-9106

$\mathrm{Ph}$.D. in Social Sciences with a specialization in Political Science from the Facultad Latinoamericana de Ciencias Sociales, FLACSO México; Research Professor at Facultad Latinoamericana de Ciencias Sociales, FLACSO México. E-mail: jeraldinedelcid@gmail.com 